
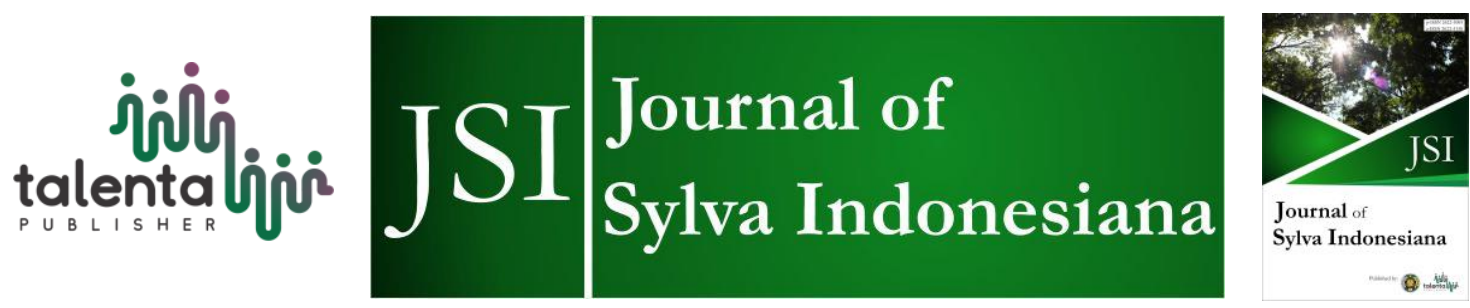

\title{
Adaptability of Kemenyan Toba (Styrax sumatrana) and Suren (Toona sureni) on Gold Mining Tailing
}

\author{
Arida Susilowati $^{1}$, Alfan Gunawan Ahmad ${ }^{2}$, David Raymod Sirait ${ }^{3}$ \\ ${ }^{1,2,3}$ Faculty of Forestry, Universitas Sumatera Utara, Medan, Indonesia
}

\begin{abstract}
Tailing was residue of gold mining process which leads to some environment problem. Beside containing heavy metal, tailing has lower of soil fertility, physical, chemical and biological characteristics. To overcome this problem, revegetation activities was needed. The successfulness of revegetation activities determined by adaptive trees selection. Local species was recommended because suitable to local climate and soil conditions, in this study we have chosen kemenyan toba (Styrax sumatrana) and suren (Toona sureni). The objective of this research was to get information about the adaptability of kemenyan toba and suren on growth media containing tailings. The research was conducted in the Faculty of Agriculture's greenhouse, University of Sumatera Utara. Factorial Randomized Completely Design with two factors was used in this research. The first factor was growing media (Factor A) and the second factor was seedling species (Factor B). The observed parameters were seedling height, seedling diameter, seedling dry weight, primary root length, root-shoot ratio and chemical properties of media. The results showed that the species and growth media significantly affected the height growth of seedlings, diameter, dry weight and length of primary root. The addition of topsoil and compost able to improve of chemical properties of tailings. Tailings media and compost with the composition ratio of 1:1 was recommended for kemenyan toba and suren.
\end{abstract}

Keyword: Compost, Suren, Tailing, Toba Benzoin, Topsoil.

Received 27 October 2017| Revised 28 January 2019| Accepted 2 April 2019

\section{Introduction}

Tailing was the gold mining residue that still containing heavy metal and released toxic. Tailing from gold mining commonly contain a high level of heavy metal such as arsenic, cadmium, mercury, and lead [1]. Due to this residue, ex-gold mine land has lower soil fertility, physical, chemical, and biological properties. That condition has become such a problem that needs to be solved by land rehabilitation, especially on revegetation programs.

\footnotetext{
*Corresponding author at: Faculty of Forestry, Universitas Sumatera Utara, Padang Bulan, Medan 20155, Indonesia E-mail address: arida_iswanto@yahoo.co.id
} 
Revegetation program is a technique that can be applied as an effort to rehabilitate damaged land [2]. For the successfulness of revegetation program, adaptive species were prefered based on suitable to growth in ex-mining. Revegetation programs require local species because more adaptable to the local climate and local soil condition [3]. Revegetation using local species also can support other species to grow and tend to restore the ecosystem environment closer to its original condition [4].

Kemenyan toba (Styrax sumatrana) and suren (Toona sureni) have been widely cultivated by local people in North Sumatra. Kemenyan toba was a native species and known as rosin producing trees [5]. While suren, or locally known as ingul, was an interesting species for the Bataknese tribe because it fast-growing properties and can be utilized as raw materials for some purposes. By using preferable native species, future revegetation program will be success. The information on utilization kemenyan toba and ingul for rehabilitation program is still not obtained yet. Based on these consideration, our research was conducted to get information the adaptability of kemenyan toba (Styrax sumatrana) and suren (Toona sureni) in tailing media.

\section{Materials and Method}

\subsection{Materials}

The research was carried out in Faculty of Agriculture's greenhouse, University of Sumatera Utara. Tailing as planting media originated from Huta Bargot Julu Village, Huta Bargot Subdistrict, Mandailing Natal, North Sumatera. Litter compost and topsoil were used as additions on planting media combination. The kemenyan toba and suren seedlings were obtained from nursery belongs to Aek Nauli Forest Research Agency.

\subsection{Method}

Before being used on the adaptability test, kemenyan toba and suren seedlings should be acclimated and conditioned for 2 weeks to avoid stress due to two differences of greenhouse location. The planting media has been sterilized and given fungicide to avoid pathogens that can cause the death of seedlings. The combination of planting media was mining soil 100\% (B1), topsoil (B2), mining soil:compost 1:1 v/v (B3), mining soil:compost 1:2 v/v (B4), and mining soil:topsoil 1:1 v/v (B5).

Adaptability observation activities were carried out after the seedlings were ready for planting and the media was ready for used. Planting was done by filled planting media into polybags that are $20 \times 30 \mathrm{~cm} 2$ in size. The study was designed using a Factorial Completely Randomized Design with 2 factors, those were type of media (factor A) and plant species (factor B) with 3 replications on 3 tree plots. Maintenance activities was done by watering the plant every morning or depend on plants requirement. The plants were watered using a plastic dipper at the soil surface and the leaves were watered using a small sprayer to provide the leaves stay fresh 
and not withered. Observations of seedling adaptability were carried out directly every week based on parameters of plant height, plant diameter, root-shoot ratio, dry matter produced, and primary root length. Observation of soil chemical properties was carried out in the central laboratory, Faculty of Agriculture, University of Sumatera Utara.

\section{Results and Discussion}

\subsection{Chemical Condition of Soil from Ex-Gold Mine}

The observed soil properties in this study were the degree of soil acidity $(\mathrm{pH}), \mathrm{C}$-organic, $\mathrm{N}$ total, P Bray, K-exch, Al-exch and cation exchange capacity (CEC) (Table 1). Observation analysis of soil chemical properties (Table 1) shows that all parameters value was under the standard. Tailing $\mathrm{pH}$ value was 4.87 , notably acidic. That condition inhibited plant growth because some nutrients become unavailable. C-organic on tailing also under the standard $(0.11 \%)$. According to [6], organic matter influences the aggregate formation of soil structure (granulator), then it can improve root penetration and increasing soil resistance to erosion. Organic matters also can increase water holding capacity on soil and nutrients absorbability (soil CEC increased) and become an energy source for the microorganism. In other words, organic matter content on the soil is directly proportional to soil CEC. The CEC on mining soil was $5.42 \mathrm{me} / 100 \mathrm{~g}$ (low). Nitrogen content on mining soil was $0.10 \%$ (low). According to [7], the deficiency of nitrogen content will lead to visual symptoms, may cause yellowing of leaves.

Table 1 The result of chemical properties analysis of ex-gold mine (tailing)

\begin{tabular}{lllll}
\hline Parameters & unit & Standard value & Mining land & Description \\
\hline $\mathrm{pH}$ & & $6-7$ & 4.87 & acidic \\
C-organic & $\%$ & $11-15$ & 0.11 & very low \\
N-total & $\%$ & $0.21-0.5$ & 0.10 & low \\
P-avl (Bray II) & Ppm & $16-25$ & 8.10 & very low \\
K-exch & me/100g & $0.3-0.5$ & 0.44 & moderate \\
CEC & me/100g & $17-24$ & 5.42 & low \\
Al-exch & me/100g & & 2.19 & high \\
\hline
\end{tabular}

Description: The assessment of soil properties was based on criteria for assessing the soil properties [8]

Phosphorus contain in mining soil was $8.10 \mathrm{ppm}$ and considered as low concentration. Lack of phosphor will hinder the plant growth because obstructed the cell development. The indication can be shown with the change of leaves color turning into purplish brown starting from leaf tip. Potassium (K) content was considered as a medium concentration with $0.44 \mathrm{me} / 100 \mathrm{~g}$.

$\mathrm{Al}$-exch is an exchangeable aluminum content in the soil. Al-exch is generally contained on land that has an acidic character or with less than 5 in $\mathrm{pH}$. Higher aluminum saturation would be toxic to the plant. The value of Al-exch in this research was considerably high with 2.19 me/100g. According to [9] toxication of aluminum would hinder the growth and extension of primer roots, and obstructed the establishment of lateral roots and root hair. If roots grow was 
obstructed, nutrient uptake and organic compound will get disturbed. Based on the result of the analysis, it can be concluded that the condition of ex-gold mine soil in Huta Bargot Julu village, Huta Bargot district, Mandailing Natal regency was a marginal soil with poor nutrient. With that condition, it is important to improve the physical or chemical soil quality.

\subsection{The Result on Chemical Analysis of Treatment Media}

Topsoil and compost addition showed the increasing parameter value on each media, even though some parameter has not reached the standard (Table 2). Increasing $\mathrm{pH}$ was found in every treatment. The highest $\mathrm{pH}$ was found on $\mathrm{A} 3$ (7.76), while the lowest $\mathrm{pH}$ was found on $\mathrm{A} 2$ and A5. Addition of compost increased the $\mathrm{C}$-organic in this research.

Table 2 Characteristics of planting media

\begin{tabular}{llllllll}
\hline Parameters & Unit & $\mathrm{A}_{1}$ & $\mathrm{~A}_{2}$ & $\mathrm{~A}_{3}$ & $\mathrm{~A}_{4}$ & $\mathrm{~A}_{5}$ & Standard \\
\hline $\mathrm{pH}$ & --- & 4.87 & 5.74 & 7.76 & 7.49 & 5.74 & $6-7$ \\
C-organik & $\%$ & 0.11 & 3.04 & 2.65 & 2.58 & 1.50 & $3-5$ \\
N-total & $\%$ & 0.10 & 0.21 & 0.24 & 0.16 & 0.14 & $0.21-0.5$ \\
P-avl (Bray II) & $\mathrm{Ppm}$ & 8.10 & 7.92 & 22.25 & 29.61 & 9.23 & $16-25$ \\
K- exch & $\mathrm{me} / 100$ & 0.44 & 0.37 & 0.62 & 0.45 & 6.13 & $0.3-0.5$ \\
KTK /CEC & $\mathrm{me} / 100$ & 5.42 & 2.64 & 14.56 & 24.96 & 39.68 & $17-24$ \\
Al-dd & me/100 & 2.19 & $\mathrm{Tt}$ & $\mathrm{tt}$ & $\mathrm{Tt}$ & $\mathrm{Tt}$ & --- \\
\hline Description: The assessment of soil properties & \multicolumn{7}{c}{ was based on criteria for assessing the soil properties [8]. }
\end{tabular}

\subsection{Adaptability of Kemenyan Toba (Styrax sumatrana) and Suren (Toona sureni) on Different Planting Media.}

Variance analysis (Table 3) shows plant species produce the significant efect on plant height, diameter, root length parameters and dry matter. While media type is significant towards plant height, plant diameter, and primary root length. The interaction between the plant types is significant towards plants height. The post-hoc test, Duncan's multiple range test (DMRT) (Table 4), shows that suren produced a larger diameter average than kemenyan toba in every treatment. Combination of mining soil media: compost $(1: 1 \mathrm{v} / \mathrm{v})$ produced better diameter growth on all type of plants.

Table 3 Duncan's multiple range test (DMRT) type of plant and planting media through the plant growth

\begin{tabular}{llllll}
\hline Variance & P value & & & \\
\cline { 2 - 6 } & Height & Diameter & $\begin{array}{c}\text { Dry matter } \\
\text { produced }\end{array}$ & Root-shoot ratio & $\begin{array}{c}\text { Length of } \\
\text { primary root }\end{array}$ \\
\hline $\begin{array}{l}\text { Planting media } \\
\text { (A) }\end{array}$ & $0.000^{* *}$ & $0.002^{* *}$ & $0.166 \mathrm{tn}$ & $0.281 \mathrm{~ns}$ & $0.000^{* *}$ \\
Type of plant (B) & $0.000^{* *}$ & $0.000^{* *}$ & $0.044^{*}$ & $0.966 \mathrm{~ns}$ & $0.000^{* *}$ \\
Interaction (AXB) & $0.001^{* *}$ & $0.506 \mathrm{tn}$ & $0.895 \mathrm{~ns}$ & $0.926 \mathrm{~ns}$ & $0.408 \mathrm{~ns}$ \\
\hline $\begin{array}{l}\text { Description: } \\
* *: \text { very significant at } 99 \% \text { confidence levels, * : significant at } 95 \% \text { confidence levels, ns : not significant }\end{array}$
\end{tabular}


Table 4 The average of Duncan's multiple range test (DMRT) on several growth parameters

\begin{tabular}{lcccccccccc}
\hline \multirow{2}{*}{ Parameters } & \multicolumn{10}{c}{ Treatments } \\
\cline { 2 - 11 } & A1B1 & A1B2 & A2B1 & A2B2 & A3B1 & A3B2 & A4B1 & A4B2 & A5B1 & A5B2 \\
\hline Height & $0.97 \mathrm{a}$ & $21.63 \mathrm{a}$ & $16.80 \mathrm{~d}$ & $57.90 \mathrm{~d}$ & $9.30 \mathrm{~cd}$ & $54.40 \mathrm{~cd}$ & $3.73 \mathrm{ab}$ & $46.20 \mathrm{~b}$ & $7.67 \mathrm{bc}$ & $48.13 \mathrm{bc}$ \\
Diameter & 0.34 & 1.33 & 0.83 & 2.25 & 0.92 & 1.95 & 0.69 & 1.55 & 0.64 & 1.73 \\
$\begin{array}{l}\text { Dry matter } \\
\text { produced }\end{array}$ & 3.14 & 3.75 & 3.61 & 4.36 & 4.50 & 8.19 & 3.97 & 5.18 & 3.79 & 4.42 \\
$\begin{array}{l}\text { Root-shoot ratio } \\
\text { Lenght of }\end{array}$ & 6.60 & 8.65 & 11.78 & 10.40 & 8.19 & 8.10 & 10.77 & 9.59 & 11.29 & 12.20 \\
primary root & 3.26 & 5.90 & 5.37 & 9.43 & 4.90 & 8.81 & 4.28 & 7.71 & 4.06 & 6.96 \\
\hline
\end{tabular}

Description: values followed by the same letters in the same column are not significantly different at $95 \%$ confidence levels in accordance with Duncan's multiple range test.

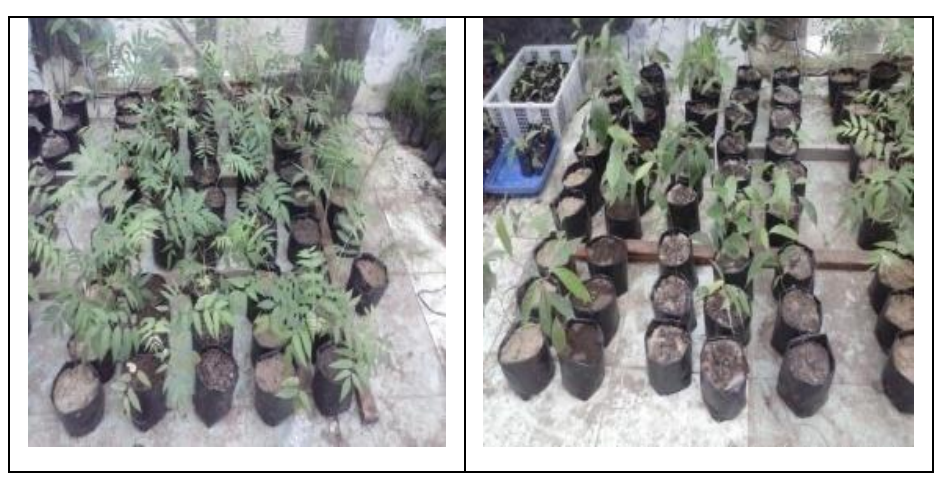

Figure 1 The diversity of kemenyan toba and suren seedlings on various growing media

\subsection{Plants Height}

The average value of suren height ranged from $21.63 \mathrm{~cm}$ to $57.90 \mathrm{~cm}$. While the average value of increment in plants height ranged from 0.97 to $16.80 \mathrm{~cm}$. The highest growth was found on A2 media and the lowest was found on A1 media.

The highest increment occurred in 100\% topsoil planting media. The topsoil contains organic material that makes the plants grow well. Meanwhile, the lowest height growth was found on the $100 \%$ mine soil. It caused by tailing material did not contain colloids that make poor of cation exchange capacity (CEC), nutrient content, and nutrient retention ability. Furthermore, high residual micro metal elements from mining materials also make lower microorganism activity [10]. 


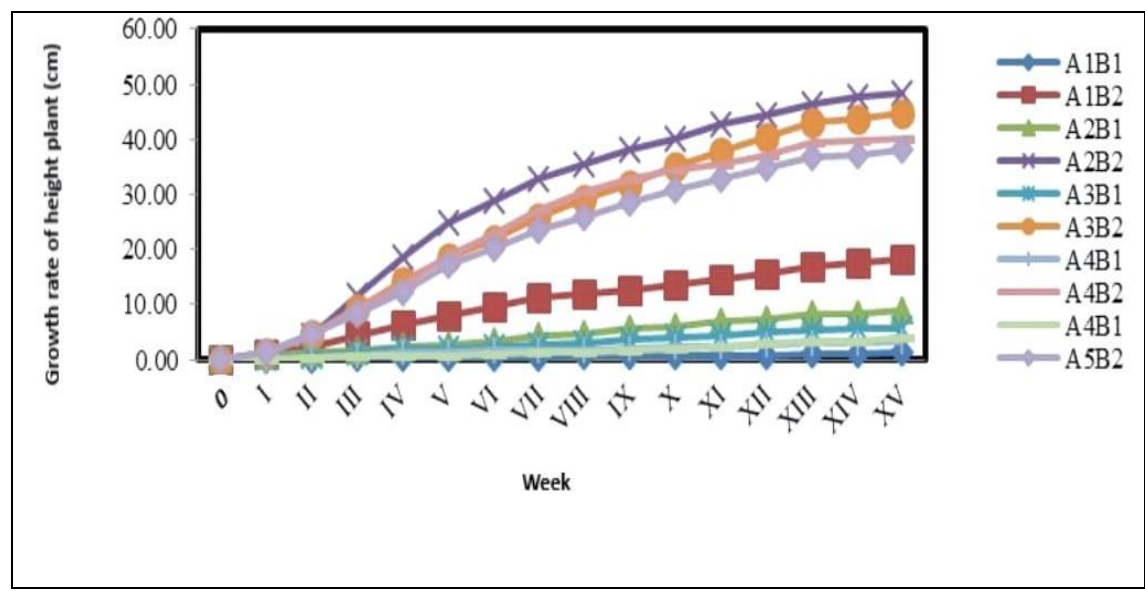

Figure 2 Plant height increment

Kemenyan has a lower ability to grow than suren. According to [11] Styrax sumatrana requires a high quality of soil fertility and intensive cultivation. According to [12] kemenyan requires good condition of porosity and can not survive in logged media. Both of condition can causing lower kemenyan growth in our observation and the death of seedlings at 4 months of observation.

Topsoil 100\% was the best planting media in this research. Topsoil media have higher calcium organic and natrium content than other planting media, which was $3.04 \%$ and $0.21 \%$ respectively. According to [13], soil organic matter is help in improving the physical and chemical properties of soil and increasing soil biota activities. The influence of high natrium nutrient condition affects the plant height. Nitrogen is an important properties for amino acids, amides, nucleotides, nucleoproteins, and essential for cell division, cell enlargement, and for growth.

\subsection{Plants Diameter}

The average of kemenyan toba's diameter ranged between 0.34 to $0.92 \mathrm{~cm}$ (Table 4). The diameter growth was found A3 media, while the lowest was found A1 media. The increment of Suren's diameter growth ranged between $1.33 \mathrm{~cm}$ to $2.25 \mathrm{~cm}$ with the highest was found in A2 media and the lowest was found in A1 media.

The highest diameter of kemenyan toba was found on a combination of planting media mining soil:compost $(1: 1 \mathrm{v} / \mathrm{v})$. Compost is an organic fertilizer made from plant and animal residues that have been decomposed, compost also has much utilization for the plant growth process. Additions of compost on tailing soil may increase the essentials nutrient, such as nitrogen $(\mathrm{N})$ and phosphorus (P). According to [14], tailing soil that combined with compost was a planting media that can provide a better growth response.

The highest increment of suren diameter was found in a combination of planting media top soil $100 \%$. Topsoil is composed complex matter and nutrients that can provide better growth. 


\subsection{Dry Matter Produced}

Dry matter able to show the products of plant photosynthesis [15]. Dry matter can be us as indicator of plant growth and development. The average dry matter of kemenyan toba was ranged between $3.14 \mathrm{~g}$ to $4.50 \mathrm{~g}$, with the highest dry matter produced was found on $\mathrm{A} 3$, while the lowest was found on planting media treatment A1 (Table 4). Kemenyan toba has a lower dry matter than suren. It showed that suren has better adaptability than kemenyan in several conditions of ex-mining land.

\subsection{Root-Shoot Ratio}

The root-shoot ratio is an important factor in plant growth which reflects the comparison between water absorption capacity and minerals with the transpiration process and plant photosynthetic area [16]. The root-shoot ratio describes the seedling's ability if planted on the soil. According to [17] the good value of root-shoot ratio ranged between 1-3.

The average of kemenyan toba root-shoot ratio ranged between 6.60 to 11.78 with the highest root-shoot ratio was found on A2, while the lowest found on A1. The average of suren rootshoot ratio ranged between 8.10 to 12.20 with the highest root-shoot ratio was found on A5, while the lowest root-shoot ratio was found on A3.

The highest root-shoot ratio value indicates the shoot growth was higher than root growth. It also showed that the plants that have small and short roots, can support a plant with large volume and length to provide water and nutrients. While the plant with deficiency water and nutrients will form more roots that can increase the nutrients uptake which can produce the low value of the root-shoot ratio [18].

\subsection{Primary Root Length}

The average value of the primary root length of kemenyan toba ranged between $3.26 \mathrm{~cm}$ to 5.37 $\mathrm{cm}$. The shortest primary root was found in A1, while the longest primary roots found in $\mathrm{A} 2$ (Table 4). The average value of the primary root length of suren ranged between $5.90 \mathrm{~cm}$ to 9.43 $\mathrm{cm}$ with the shortest primary root was in A1 and the longest was in A2. According to [19], root growth was affected by soil physical conditions. Soil compaction will change the soil porosity (structure and pores) so that the water content also changes. High-density soil makes the plant roots become shorter. This is in accordance with [20], who stated that if the density of soil is raising then macropores column declined and root penetration is blocked.

\section{Conclusion}

Suren were more adaptive compared to kemenyan toba on observed tailing media. Based on the chemical characteristics analysis, the combination of compost and topsoil produce the best value 
and make the plants grow better. The best planting media for growing kemenyan toba and suren in this research was the combination of mining soil and compost $(1: 1 \mathrm{v} / \mathrm{v})$.

\section{REFERENCES}

[1] F. Pearce, Tails of Woe, Minerals Policy Institute, 2000.

[2] E. Sudarmonowati, S. Novi, N.S. Hartati, N. Taryana, U.J. Siregar, "Sengon Mutan Putatif Tahan Tanah Ex-Tambang Emas," Journal of Applied and Industrial Biotechnology in Tropical Region, vol. 2, no. 2, pp. 1 - 5. 2009.

[3] E. Rachman, "Perencanaan Penanaman Untuk Rehabilitasi Hutan dan Lahan Terdegradasi di Jabar," Prosiding Dialog Stakeholders Kegiatan Rehabilitasi Lahan Kritis Berbasisi Pemberdayaan Masyarakat Pedesaan, 2008. pp. 176-186.

[4] Rahmawaty, Restorasi lahan Bekas Tambang Berdasarkan Kaidah Ekologi, Fakultas Pertanian USU Digital Library, Medan, 2002.

[5] A. Susilowati, K.S. Hartini, H.H. Rachmat, M. Alvaroby, "Propagation Of Valuable North Sumatera Benzoin Trees (Styrax Sp) Using Macrocutting Technique" In IOP Conf. Series: Materials Science and Engineering 180 : 012046. DOI: 10.1088/1757-899X/180/1/012046, 2017.

[6] S. Hardjowigeno, Ilmu Tanah, PT Mediyatama Sarana Perkasa, Jakarta, 1992.

[7] M. Laegreid, O.C. Bøckman, and O. Kaarstad, Agriculture, Fertilizers and the Environment, CABI Publishing, New York, p. 294, 1999.

[8] Pusat Penelitian Tanah, Jenis Dan Macam Tanah Di Indonesia Untuk Keperluan Survei Dan Pemetaan Tanah Transmigrasi, Pusat Penelitian dan Agroklimat, Bogor, 1983.

[9] N. Hakim, M.Y. Nyakpa, A.M. Lubis, S.G. Nugroho, M.A. Diha, G.B. Hong, H.H. Bailey, Dasar-dasar Ilmu Tanah, Unversitas Lampung, Lampung, 1986.

[10] I.R. Lesmanawati, "Pengaruh pemberian kompos, thiobacillus, dan penanaman gmelina serta sengon pada tailing emas terhadap biodegradasi sianida dan pertumbuhan kedua tanaman,” Tesis, Institut Pertanian Bogor, 2005.

[11] K. Heyne, Badan Litbang Kehutanan (Terj.), Tumbuhan Berguna Indonesia Jilid I dan II, Departemen Kehutanan Jakarta Pusat, 1987.

[12] Jayusman, R.A. Pasaribu, dan S. Walpen, Pedoman Teknis Budidaya Kemenyan (Styrax spp.), Konifera Visi dan Informasi Teknis BPK Pematang Siantar, vol. 2, no.1, 2014.

[13] Notohadiprawiro, Tanah dan Lingkungan, Depdikbud, Jakarta, 1999.

[14] I.W. Dharmawan, "Pemanfaatan endomikoriza dan pupuk organik dalam memperbaiki pertumbuhan Gmelina arborea LINN pada tanah tailing," Tesis, Institut Pertanian Bogor, 2003.

[15] A.T. Ratnaningsih, "Pendugaan Kandungan Karbon pada Acacia crassicarpa di Hutan Rawa Gambut (Studi Kasus di IUPHHK-HT PT. RAPP Kab. Pelalawan)," Tesis, Universitas Riau Pekanbaru, 2006.

[16] N. F. Wulandari, C. To anun, E.H.C. McKenzie, K.D. Hyde, "Guignardia bispora and G. ellipsoidea spp. nov. and other Guignardia species from palms (Arecaceae)," Mycosphere vol. 2, no. 2, pp. 115-128, 2011.

[17] M.L. Duryea, N. Brown, "Seedling Physiology and Reforestation Success," in Proceeding of The Physiology Working Group Technical Session, Boston: DR. W. Juck Publisher, 1984.

[18] S.M. Sitompul dan B. Guritno, Analisis Pertumbuhan Tanaman, Gadjah Mada University Press, Yogyakarta, 1995. 
[19] O. Rusdiana, Y. Fakuara, C. Kusmana, Y. Hidayat, "Respon pertumbuhan tanaman sengon (Paraserianthes falcataria) terhadap kepadatan dan kandungan air tanah podsolik merah kuning," Jurnal Manajemen Hutan Tropika, vol. 6, no. 2, pp. 43-53. 2000.

[20] S. Russel, Plant Root System. Their Funtion and Interaction with the Soil, McGraw Hill Book Company (UK) Limited London, 1977. 